\title{
Productivity-Based Retrospective Voting: Legislative Productivity and Voting in the 2019 European Parliament Elections
}

\author{
Miriam Sorace *†
}

*Assistant Professor in Quantitative Politics - University of Kent; Visiting Fellow in European Politics - London School of Economics and Political Science. Email: m.sorace@kent.ac.uk

${ }^{\dagger}$ Acknowledgements: I would like to thank the anonymous reviewers for their insightful comments which greatly improved the paper, and also Luis Cavada Serralheiro for his assistance in developing the web scraping code. I am furthermore grateful for the helpful feedback received at the Amsterdam Centre for European Studies (ACES) Workshop on the 2019 European Elections Amsterdam, 30-31 January 2020. I also want to gratefully acknowledge the financial support from the London School of Economics' European Institute 2018/2019 Seed Fund 


\begin{abstract}
Are European Parliament elections used to pass judgment on the legislative behaviour of parties serving in the European Parliament (EP)? Do Europeans give a bonus in EP elections to political parties whose members were highly active during the legislative term? The paper will focus on the role of legislative activities in the 8th European Parliament term (2014-2019) in informing the 2019 vote choice. The analysis combines the European Election Studies (EES) 2019 Voter Study data with original legislative behaviour data, as well as with data on European electoral systems. The evidence points to productivity-based retrospective voting being a feature of the 2019 elections. Further, the analysis finds that this type of retrospective voting is stronger in countries where electoral rules encourage candidates to promote past legislative records in electoral campaigns, and particularly so for voters that paid attention to the EP campaign in such systems. This has significant implications for retrospective voting and for the EU elections literatures, since it is evidence that the very demanding democratic desiderata of retrospection can be met in multilevel and supranational contexts as well.
\end{abstract}

Keywords: European Parliament Elections; Retrospective Voting; Accountability. 


\section{Introduction}

A central requirement of democracy is that voters should be competent and wellinformed. Assessing the past records of elected representatives is considered an optimal strategy to cast competent, well-informed votes. V.O.Key, for example, concluded that 'voters are not fools' (Key 1966 :7) after finding evidence of competent retrospection in the American public. Anthony Downs (1957) also placed heavy emphasis on past records evaluations as the ideal strategy to accurately predict the nature and future behaviour of elected representatives. The argument goes that while voters might be ignorant of their own and of parties' positions on various policy matters, their capacity to competently evaluate past records will be necessary and sufficient to gauge politicians' nature and skills, and to reward or sanction elected representatives appropriately. Many studies find that voters in advanced democracies do vote retrospectively (Healy and Malhotra 2013). Does retrospective voting apply in the context of European Parliament (EP) elections?

More specifically, the paper investigates 'productivity-based retrospective voting' in the context of the 2019 EP elections. While policy outputs - such as economic outcomes - are the yardstick used to evaluate incumbent executives, measures of productivity and hard work are better signals in legislative elections, especially in non-parliamentary systems (McDermott and Jones 2003). Moreover, legislative productivity is easy to observe and universally considered a proxy of good, trustworthy politicians (Papp and Russo 2018). 'Valence' indicators are considered more appropriate to successfully engage in retrospection since they are less likely to be subject to bias (Ferejohn 1986).

We know that performance voting targeting a) domestic executives' action (secondorder voting); and/or b) EU economic policies (economic voting) are features of EP 
elections (Reif and Schmitt 1980, Hix and Marsh 2010, Hobolt and De Vries 2016). But do EP elections serve to pass judgment specifically on the performance and productivity of parties serving in the European Parliament, thus working as EP-specific accountability devices? If that is the case, we can conclude that EP elections meet important democratic desiderata (Carey and Shugart 1995, McDermott and Jones 2003, François and Navarro 2019, Papp and Russo 2018).

The paper innovatively applies the retrospective voting framework to EP elections by linking voting behaviour and legislative activities at the EP level. The analysis explores EP elections on their own term, avoiding comparisons in terms of parties' vote share changes or vote switching behaviour from previous national elections. Voter-party dyads will be analysed instead, via data stacking. The dependent variable captures whether the respondent voted (1) or not (0) for each national party contesting the 2019 EP elections in his/her country. Party performance will be measured using legislative participation records from the 8th term of the EP, instead of relying on perceptions of EU performance captured via surveys.

The findings show that, controlling for other relevant party characteristics and for ideological proximity with voters, voters are more likely to support parties whose members were more active in the EP. EU-level activity is therefore associated with electoral choice in EP elections, and the effect is stronger in context where the electoral rule encourages candidates to publicise their past legislative records, particularly for voters that paid attention to the EP campaign. Competent retrospective voting is typically considered an unusual feat: that we see emerging evidence of the productivity-based type of retrospective voting in the 2019 elections is therefore a crucial finding, and one that fundamentally challenges the characterisation of EP elections as mere barometers of national politics. 


\section{Literature Review: The Retrospective Voting Model and EP Elections}

Retrospective voting refers to the act of evaluating past performances to reward or sanction elected representatives. The model originated in the works of Key (1966), Downs (1957) and Fiorina (1981) who theorised that a responsible, rational electorate learns and updates information using past experience, and votes on the basis of evaluations of past behaviour. The literature on retrospective voting is dominated by the study of the role of past economic performance for the evaluation of incumbent executives. Fiorina $(1978)$ argues that the state of the economy constitutes a relevant and appropriate heuristic to assess incumbents, a heuristic that can be used even by the least politically informed and attentive individual, since payoffs are more easily observable than actions. A substantial economic voting literature emerged showing that incumbents are indeed rewarded when the economy goes well and punished when it performs badly (Fiorina 1978, Lewis-Beck and Stegmaier 2000).

Recent research however demonstrates that voters make systematic errors in evaluating economic performance and attributing responsibility for economic conditions, both because of cognitive constraints - such as the availability heuristic Kramer 1971, Bartels 2008) - and because of group-serving bias (Bartels 2002,

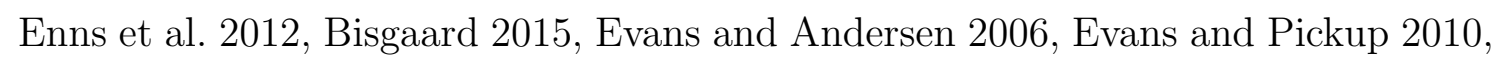
Tilley and Hobolt 2011, Sorace and Hobolt 2020). This calls into question the assumption that economic performance is easily observable and 'digested' by voters. Moreover, it is questionable that a single policy area should form the sole basis of retrospective evaluations (Healy and Malhotra 2013, Achen and Bartels 2017). More recent literature on retrospective voting focuses on alternative policy indicators. Some studies have discovered links between war casualties, disaster relief 
responses, corruption scandals, student education performance, and public safety for incumbents' re-election prospects (Healy and Malhotra 2013, Ferraz and Finan 2008, Berry and Howell 2007). In holding legislators accountable - and not just members of the executive branch - however, relying on policy outcome indicators is still problematic.

Some retrospective voting studies have thus started to focus on legislative performance and productivity indicators. These studies broadly find that, in advanced democracies, working hard in parliaments/congresses is rewarded by voters (Carey and Shugart 1995, Papp and Russo 2018, McDermott and Jones 2003). Sponsoring and initiating bills, for example, is associated with larger vote shares (Bowler 2010, Loewen et al. 2014, Däubler et al. 2016, Marangoni and Russo 2018). Legislative reports and oral questions/interpellations or motions also carry an electoral advantage for more productive politicians (François and Navarro 2019, Marangoni and Russo 2018, Däubler et al. 2018, Kellermann 2013). Receiving leadership positions (prestigious committees and influential roles within the legislature) also leads to higher re-election chances, though this appears driven by party leaderships' selection processes (Hermansen 2018, Frech 2016). Higher attendance levels are also prized by voters (Däubler et al. 2018). There is further evidence that information on legislative productivity does get out, since knowledge of parliamentarians increase with legislative productivity (François and Navarro 2020). The flourishing of web pages ranking politicians according to their productivity in the legislature is a case in point (Edwards et al. 2015).

The study of retrospective voting in EP elections follows the same trends of the general retrospective voting literature in that it heavily focuses on the performance of executives and on economic indicators. The core findings is that EP elections often act as 'referendums' on domestic executives, which earned them the charac- 
terisation of 'second-order' elections (Hix and Marsh 2010, Reif and Schmitt 1980, Ferrara and Weishaupt 2004, Marsh and Mikhaylov 2010). The performance of the domestic and of the EU economy in informing vote choice in EP election has also been investigated: the effects of national economic cycles are mixed and inconsistent (Kousser 2004, Tilley et al. 2008, Okolikj and Quinlan 2016), while EU-specific economic performance matters. People that report being adversely affected by the Eurozone crisis tend to be more likely to vote for Eurosceptic parties, demonstrating a clear impact of European-level economic evaluations on voting behaviour in EP elections (Hobolt and De Vries 2016).

The analysis of productivity-based retrospective behaviour in the context of EP elections is lagging: Hobolt and Høyland (2011) find that parties that put forward high quality candidates with high political competence are rewarded electorally. Candidate quality is however measured as political experience in the national arena and does not directly tap into EU-specific records. Van Thomme et al. (2015) tested the role of EP-specific political experience for individual MEPs' re-election chances in the 2014 election. They find that leadership positions in the EP matter for individual MEPs' re-election. However, due to the focus on individual MEPs reelection prospects, the effect is likely endogenous and confounded with intra-party politics: party leaderships may put forward such candidates both for EP leadership positions and also higher up in their candidates list, which may boost individual MEPs' electoral success.

This study will instead aggregate MEPs' behaviour by party and test the role of party-characteristics for individual-level vote choice. The paper advances both the emerging branch of productivity-based retrospection, while at the same time advancing our knowledge on the nature of EP elections. 


\section{Theory: Why does Productivity Matter?}

Borrowing from the principal-agent model, voters (the principals) have to delegate authority to elected representatives (the agents), and also need to limit agency drift. To prevent moral hazard from agents, principals have two core strategies available: (a) stringent ex ante evaluation - e.g. drafting contracts/exacting promises (prospective evaluation); or (b) ex post monitoring of agent's concrete actions, using performance indicators (retrospective evaluation). The latter is considered to be the most efficient strategy to evaluate the suitability and good-naturedness of the agent and thus prevent moral hazard. This is because confiding simply in prospective signals (such as professed ideology and electoral manifestoes) is risky, since political agents could easily lie, making such signals 'cheap talk'. Prospective voting - while less costly and therefore pervasive (Downs 1957) - is seen as sub-optimal in terms of democratic accountability (Ferejohn 1986, Fiorina 1981). Past records provide better information on future performance and, therefore, are a more accurate basis to assess the true nature of an agent (Besley 2006, Healy and Malhotra 2013). To put it simply, as the nature of an agent is fundamentally hidden, only concrete action can reveal it.

Different past performance indicators could be adopted to monitor political agents. Economic performance has been the indicator of choice in most studies of retrospective voting, but recent research has demonstrated that the processing of economic information is too complex for voters, and prone to cognitive biases (Bartels 2002, Enns et al. 2012, Sorace and Hobolt 2020). Moreover, economic performance is not an appropriate indicator for all types of elected representatives (Healy and Malhotra 2013). To engage in successful retrospective voting one should adopt easily observable past outcomes that have universal valence (Ferejohn 1986): 
economic performance indicators do not seem to fulfil these requirements.

Parliamentary work better approaches Ferejohn's (1986) desiderata: measures of parliamentary activity are quick and easy to understand, and productivity is a universally-recognised good quality to possess, which can work as a proxy for the quality of political agents (Papp and Russo 2018). That productivity is a useful heuristic to gauge the nature of political agent is demonstrated by the close monitoring of legislative participation by interest groups, who reward the more productive legislators with more substantial campaign contributions (Grier and Munger 1986). Party leaderships also appear to value productivity and leadership roles within the legislature (Hermansen 2018, Frech 2016). Political and interest group leaders, therefore, clearly think that legislative productivity is a fundamental indicator to identify good agents. Voters in advanced democracies seem to agree: while some argue a distinction between 'show-horse' and 'work-horse' activities needs to be made (Payne 1980, Papp and Russo 2018), there is broadly an association between legislative effort and vote choice, also demonstrated by the finding that legislators appear to boost their engagement in various legislative activities when they are under heightened electoral risk (Mayhew 1974, Kellermann 2013).

This paper aims at evaluating whether European Parliament elections also show signs of productivity-based retrospective voting, and therefore its goal is to test the following main hypothesis:

H1: The more productive the party's MEPs are, the higher the likelihood voters will vote for the party in the next EP election.

The mechanism that links parties' parliamentary activity and individual-level vote choice is voters' awareness of and attentiveness to elected representatives' leg- 
islative records. The recent proliferation of websites tracking parliamentarians activity levels attest to the simplicity of, and to the public appetite for, such indicators of past performance (Edwards et al. 2015). That citizens during elections are interested in what politicians concretely did while in office is also highlighted by website activity data during the 2019 EP elections. Using Alexa's (Alexa 2020) website traffic data it is possible to compare the rankings of the most famous website recording MEPs legislative activities: votewatch.eu; mepranking.eu; and yourvotematters.eu. Figure 1 below reports each website's popularity ranks between summer 2018 and January 2020. Larger numbers mean the website was not popular while smaller numbers denote an increase in the website's popularity: the y-axis is therefore 'flipped'. It is clear from the graph that these websites witnessed a spike in popularity from end of March 2019 until Summer 2019, to then go back to their normal rank position (around 1m). By exploring the underlying dataset, the surge is particularly pronounced in the European election week (20-26 May 2019). Figure 2 below is taken from Alexa's Audience Overlap Tool Alexa 2020 which captures websites that share the same audience as the target websites (VoteWatch, MEPRanking and YourVoteMatters). Figure 2 highlights the strong connection that the target websites have with voting, since they share audiences more often with voting advice application sites. This suggests that citizens trying to get information online about European elections are interested in learning about MEPs' past records.

The data above is only suggestive of the mechanism linking legislative productivity and vote choice: it does not give us a sense of the representativeness of the website users, for example: usually the highly engaged and educated get informed online (Edwards et al. 2015). We need a different indicator to determine in which contexts this information is more widely available. Studies of EU coverage in the media show that EU coverage is context-dependent, and that it has consistently 


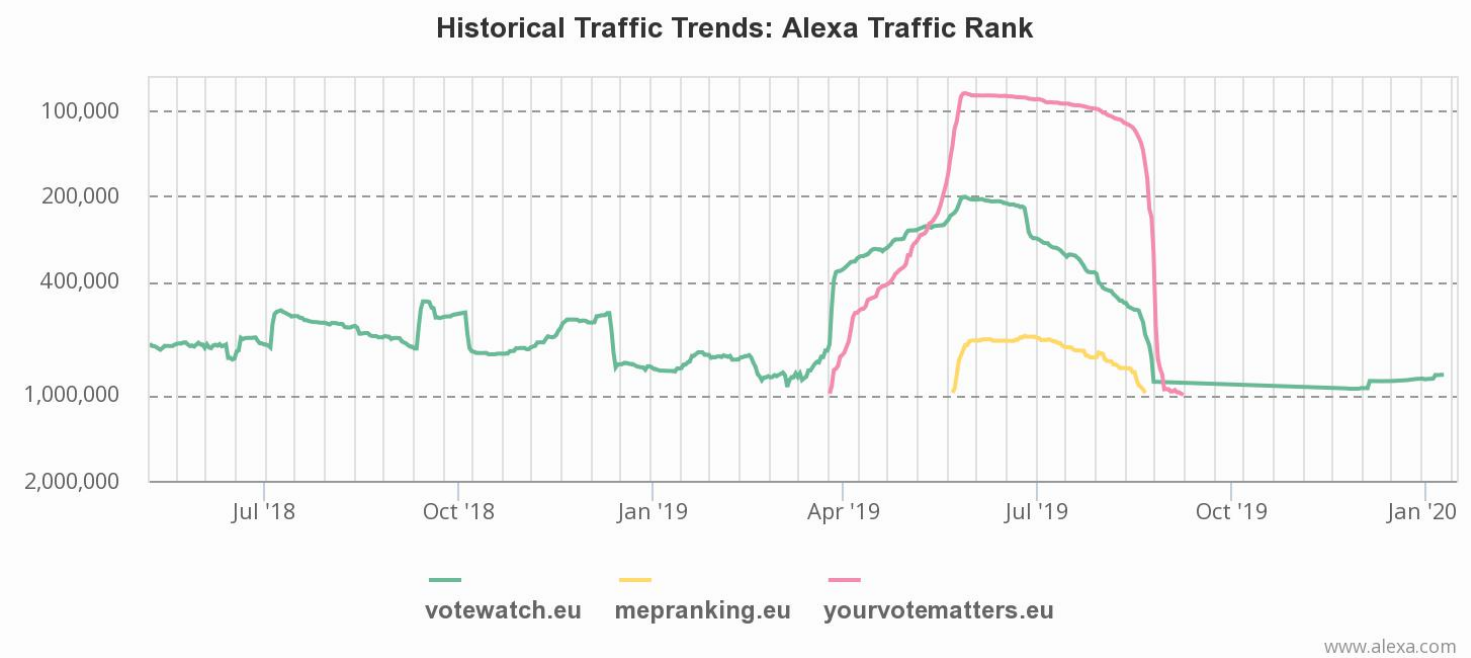

Figure 1: Alexa Traffic Ranks for VoteWatch, MEPRanking and YourVoteMatters Note: Global data.

whichcandidate.ie

votingcounts.org.ukvotecompass.com

smartwielen.luvotehelp.orgwhoshallivotefor.com yvote.eu

votematch.ey whoshouldyouvotefor.comopenpetition.eu

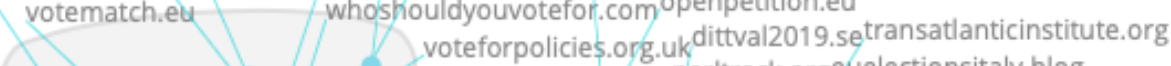

how gueryourvotematters.eưk orgeuelectionsitaly.blog

saveyourinternet.eu

gue euranetplus-inside.eu

sotelwatch.evepranking.eu lliareda.eut thistimeimvoting.europerangrfenłentmagazine du euwiki.org politix.io

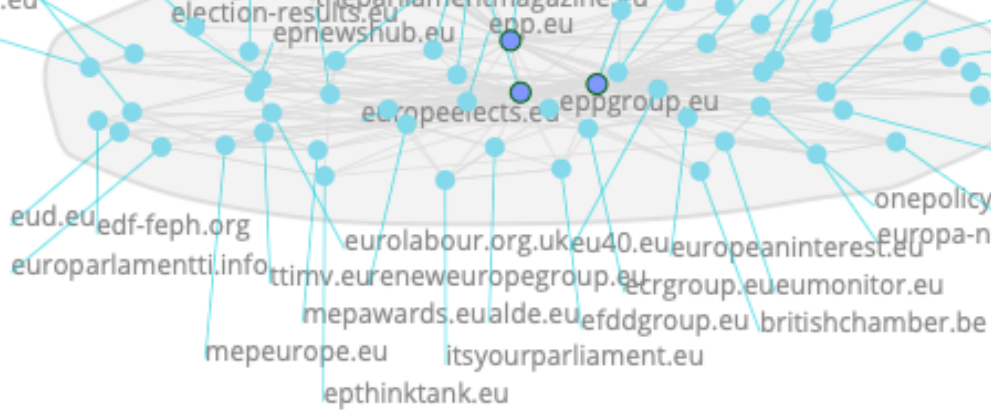

Figure 2: Alexa Website Audience Overlap Tool. Note: Global data. 
increased over time (Boomgaarden et al. 2013). However, we do not have granular time-series media coverage data that is specific to EP legislative activities.

An alternative is to exploit the variation in electoral systems, and, therefore, in electoral incentives. Different electoral rules provide different incentives to political parties to disclose legislative records. Information about past legislative records is more likely to be made public in countries where electoral systems favour the personal vote (Däubler et al. 2018). Studies do find that electoral rules that encourage personal branding cause legislators to do more constituency work (Farrell and Shugart 2012), to sponsor more bills (Bräuninger et al. 2012), and to deliver more speeches (Proksch and Slapin 2012). Clearly legislative activism is considered electorally valuable by legislators elected under such electoral systems. To identify electoral systems that motivate legislators to seek out the personal vote, European countries will be classified according to (a) the ballot structure; and (b) the district magnitude of their electoral system, following Carey and Shugart (1995). Closed ballot structures (votes for party symbols, lists fixed by the party leadership) should result in lower incentives to seek the personal vote, and this should be particularly the case if closed ballots are coupled with large districts (or nation-wide districts). Conversely, preferential systems (STV, semi-open ballots or open ballots) are more likely to strongly motivate candidates to seek a personal vote, and especially so in large district magnitude systems (Carey and Shugart 1995).

If the association between party's EP productivity and its electoral support is stronger in electoral systems which encourage the personal vote - and thus the disclosure of legislative records information - this would strengthen the claim that past legislative activity records are directly linked to parties' electoral success. The below analysis therefore tests the expectation that the relationship between legislative activity and electoral support is stronger where information about legislative activities 
is available and accessible to voters.

The following hypotheses are derived:

H2a: The relationship between the party MEPs' legislative productivity and the party's electoral success will be stronger in electoral systems that encourage the personal vote than in systems that do not encourage the personal vote.

H2b: The relationship between the party MEPs' legislative productivity and the party's electoral success will be stronger in electoral systems that encourage the personal vote than in systems that do not encourage the personal vote, particularly for voters that paid attention to the electoral campaign. 


\section{Data Analysis and Results}

Data from the 2019 European Election Study (EES) (Schmitt et al. 2019) was stacked in order to maximise the number of parties studied and to allow to study the effect of party characteristics on vote choice (Van der Eijk et al.|2006). Stacking the dataset means that each individual respondent is repeated $n$ times, according to how many political parties are there in the party system. The dependent variable - vote choice - will be a 1 if the individual voted for the relevant party in the dyad and 0 if the individual did not vote for the party. The voter-party dyad is therefore the unit of analysis of this study, and party covariates are the explanatory factors of interest. Non-voters or people failing to recall their vote at the 2019 parliament election were excluded from the analysis.

The data has a clear hierarchical structure with voter-party dyads being nested within voters (the repeated observations) and countries. A multilevel logistic regression model was therefore fit to the data, to take into account these dependencies in the data, and to control for respondents' and country-level confounders. The effects of individual-level characteristics are not of interest in this analysis, and are therefore subsumed into random effects, or, as a robustness test, into fixed effects (see Table A1 in the Appendix for the robustness test using fixed effects). What is more, individual-level covariates are not directly interpretable in a stacked, dyadic regression scenario (Van der Eijk et al. 2006, De Vries and Tillman 2011). The statistical solutions proposed to obviate to this problem are not applicable to maximum likelihood estimation (Van der Eijk et al. 2006 :442), which is the estimation required by the binary dependent variable of this study. The models in this analysis therefore deals with individual-level covariates by treating individual respondents as one of the hierarchical levels in the multi-level model, a strategy which takes into 
account both variability between and within individuals. The results are reported in table 1 below.

The key independent variables of this study are Plenary Presence - in percentage terms -, and average Number of Speeches, Party Rapporteurs, and Party Committee Chairs. The measures of productivity are all expressed as party averages and thus proportionate to national party size: they do not depend on the national delegation's number of seats in the previous EP. Furthermore, they all refer to the 8th legislative term of the European Parliament, the term preceding the 2019 elections. The first variable was retrieved from the VoteWatch database 1 . It measures the extent to which each party's MEPs participated to voting sessions in the EP plenary. The remaining legislative activity variables were scraped from the MEP section of the EP official website.

These activities were chosen as they are those traditionally used in the relevant scholarship to construct legislative productivity indexes (Papp and Russo 2018). Moreover, all these activities are readily available online and receive media coverage. Sites like VoteWatch.eu and MEPRanking.eu constantly publicise MEPs' plenary participation levels and parliamentary roles. The activities chosen are a mixture of visible ('show-horse') activities - such as speeches - and policy-seeking ('work-horse') ones, such as presence during roll-call voting plenaries. Committee chairmanships and rapporteurships can be thought of possessing both show-horse and work-horse qualities. Rapporteurships and committee chairmanships, while absolutely crucial to shape policy, also reflect the visibility of the national political party and of its European Party Group, because of the way they are allocated in the EP. Chairmanships, for example, while distributed proportionally to each European Party Group's size (which, in turn, try to distribute them proportionally to

\footnotetext{
${ }^{1}$ https://term8.votewatch.eu/en/term8-voting-statistics.html
} 
the affiliated national parties) often go to loyalist MEPs with renowned expertise in the policy area: some national parties may therefore be more successful than their size would warrant (Yoshinaka et al. 2010).

To capture prospective voting, the absolute contemporaneous distance - or incongruence - of each voter from the relevant party on the left-right and EU issue dimensions were calculated from the EES 2019 data, following the spatial voting/preference coherence model (Downs 1957). The respective party positions were calculated from the average placement by the EES Voter Study respondents within each country at election time.

Crucial control variables are the party's government-opposition status, party size, and party family. Government-opposition status of each party was calculated at the time of the 2019 election and on the basis of the last national election (e.g. for elections concurrent with the 2019 EP elections, therefore, the previous national election was considered). Party size is measured as the $\%$ of the lower house seats won by the party in the previous national election. Both of these variables were collected from the Inter-Parliamentary Union database 2 . The party family variable was coded on the basis of the official websites of the Eurogroups, each listing all national members $3^{3}$. Since national parties coalesce into European Party Groups on the basis of ideological congruence (McElroy and Benoit 2010), Eurogroup membership is assumed to validly capture parties' ideological families.

An additional control - meant to proxy partisanship - captures whether the individual voted for the relevant party in the previous (national) election (1), or not (0). This is included in the robustness analysis in the Appendix (Table A2): the results are in line with the results presented below. Due to the lack of any theoretical

\footnotetext{
2 https://data.ipu.org/

3 https://www.europarl.europa.eu/politicalparties/index_en.xml
} 
expectation regarding the antecedent relationship between the individual's prior vote choice and the party's volume of EP activities (the key independent variables), this control is not included in the main analysis, as it muddles the theoretical model. The fact that its inclusion does not alter key inferences is however reassuring. It is instead fundamental to control for governing status, party size, and EPG affiliation since these covariates might have an impact both on the level of legislative activity and also on electoral choice, therefore posing important causal inference threats. They are also key variables in the standard second-order voting model, and thus important to include in the study.

The first model presents the results from the productivity-based retrospective voting model, where parties' activity levels in the preceding EP term are the key independent variables and other relevant party characteristics act as controls. 2 out of 4 legislative activity variables are statistically significantly associated with the party vote in the expected direction. In particular, a shift of $1 \%$ in attendance to EP voting sessions, leads to a $0.8 \%$ increase in the odds of voting for the relevant party, controlling for party size, ideological family and governing status. A $10 \%$ shift in plenary attendance thus increases the odds of party support by $8 \%$. Parties whose MEPs attend plenaries at higher rates clearly appear to benefit electorally in EP elections. The effect runs in the opposite direction for speeches: every additional speech made in the 8th EP legislative term by party members is associated with a decrease of $0.02 \%$ in the odds of voting for the party. A party that delivers 50 more speeches is predicted to decrease the odds of voting for the party by $1 \%$. This effect runs against the hypothesis, but may be explained by the nature of this particular legislative activity: legislative speech is often a position-taking ('show-horse') tool, heavily controlled by party leaders, and may be negatively perceived as an highly staged, empty activity, disconnected from substantive policy-making (Proksch and 


\begin{tabular}{|c|c|c|c|}
\hline & $\begin{array}{c}(1) \\
\text { Productivity }\end{array}$ & $\begin{array}{c}(2) \\
\text { Ideology }\end{array}$ & $\begin{array}{c}(3) \\
\text { Full }\end{array}$ \\
\hline$\%$ Plenary Presence & $1.008(0.00155)^{* * *}$ & & $1.004(0.00167)^{*}$ \\
\hline \# Speeches by Term & $1.000(0.0000497)^{* * *}$ & & $1.000(0.0000546)^{* * *}$ \\
\hline \% MEPs Rapporteurs & $1.000(0.000415)$ & & $1.001(0.000466)^{+}$ \\
\hline$\%$ MEPs Chair & $1.002(0.000524)^{* * *}$ & & $1.001(0.000577)^{+}$ \\
\hline Left-Right $\Delta$ & & $0.665(0.00503)^{* * *}$ & $0.666(0.00504)^{* * *}$ \\
\hline EU Issue $\Delta$ & & $0.917(0.00569)^{* * *}$ & $0.917(0.00570)^{* * *}$ \\
\hline Government Party & $1.000(0.0262)$ & $0.920(0.0257)^{* *}$ & $0.906(0.0260)^{* * *}$ \\
\hline Party Size & $1.032(0.00103)^{* * *}$ & $1.034(0.00113)^{* * *}$ & $1.034(0.00114)^{* * *}$ \\
\hline GUE/NGL & $0.840(0.0388)^{* * *}$ & $0.977(0.0490)$ & $1.012(0.0519)$ \\
\hline S\&D & $1.112(0.0325)^{* * *}$ & $1.224(0.0393)^{* * *}$ & $1.236(0.0400)^{* * *}$ \\
\hline GREENS/EFA & $0.991(0.0417)$ & $1.010(0.0461)$ & $1.008(0.0462)$ \\
\hline $\mathrm{ALDE} / \mathrm{RE}$ & $0.799(0.0289)^{* * *}$ & $0.726(0.0274)^{* * *}$ & $0.738(0.0289)^{* * *}$ \\
\hline ECR & $0.855(0.0387)^{* * *}$ & $0.886(0.0426)^{*}$ & $0.897(0.0437)^{*}$ \\
\hline $\mathrm{ENF} / \mathrm{ID}$ & $2.080(0.136)^{* * *}$ & $2.398(0.139)^{* * *}$ & $2.773(0.197)^{* * *}$ \\
\hline NI & $0.903(0.0533)+$ & $0.873(0.0530)^{*}$ & $0.944(0.0609)$ \\
\hline Variance Component (Country) & $1.078(0.0229)^{* * *}$ & $1.116(0.0344)^{* * *}$ & $1.128(0.0382)^{* * *}$ \\
\hline Variance Component (Individual) & $1(2.41 \mathrm{e}-20)$ & $1(2.95 \mathrm{e}-19)$ & $1(2.11 \mathrm{e}-19)$ \\
\hline Observations & 82691 & 72373 & 72373 \\
\hline$A I C$ & 65903.7 & 54534.8 & 54514.6 \\
\hline$B I C$ & 66043.5 & 54654.3 & 54670.8 \\
\hline 11 & -32936.9 & -27254.4 & -27240.3 \\
\hline
\end{tabular}

Exponentiated coefficients; Standard errors in parentheses

${ }^{+} p<0.1,{ }^{*} p<0.05,{ }^{* *} p<0.01,{ }^{* * *} p<0.001$

Table 1: Multilevel Logistic Stacked Regression Results. Dependent Variable: Vote Choice. 1 = voted for the party in the dyad; $0=$ did not vote for the party in the dyad 
Slapin 2012). Each additional \% of MEPs being assigned a committee chairmanship increases the odds of voting for the party by $0.2 \%$. The analysis from the base retrospective model finds instead no effect of volume of rapporteurships on parties' electoral support. The strategic allocation of rapporteurships and/or their more obscure status might offer a tentative explanation for this null finding. Other work has found some ambivalent effects of rapporteurships on voting behaviour (François and Navarro 2020).

The second model adds prospective voting covariates: it tests the effect of the party's ideological distance from the voter on the likelihood to vote for that party. Incongruence in both the left-right and the EU domain is negatively associated with the odds of voting for the party, controlling for party size, government status and ideological family. In particular, an increase of one unit in the absolute distance between voter and party on the left-right scale is associated with $34 \%$ lower odds of voting for that party. Ideological distance on the EU issue dimension also matters: an increase of one unit in the absolute distance between voter and party on the Euroscepticism scale decreases the odds of voting for the party by $8 \%$. This study further confirms that the EU dimension matters in EP elections (Hobolt et al. 2009, De Vries and Tillman 2011).

The final model tests retrospective and prospective voting together. The effect of plenary attendance is robust to the full model specification, though it appears slightly attenuated. The (negative) effect of speeches on party support is also robust to the full model specification. The role of rapporteurships and chairmanship is only significant at the 0.1 level in the full model specification and runs in the expected direction, with parties filling more rapporteurships and chairmanships in the EP gaining more electoral support. Ideological distance variables are also robust to the full model specification, with nearly identical coefficients. 
As far as the control variables are concerned, governing status appears to decrease the odds of voting for a party, but the effect is not robust to all model specifications. Party size is robustly positively associated with party support: larger parties have higher odds of being voted. European Party Groups also matter: when compared to the Christian Democrat party family (the baseline) the extreme right has higher odds of being voted, as well as the S\&D, which confirms the larger drop in seat percentages suffered by the EPP in the 2019 election when compared with these other party families. Parties of the far left, ALDE and the ECR - usually small parties - appear comparatively less successful than parties affiliated with the EPP, one of the largest party families.

It is interesting to note that goodness-of-fit measures improve drastically when prospective/expressive voting variables are included, as compared to the baseline retrospective voting model, and that the best performing models includes both ideological and productivity variables. Moreover, prospective voting seems to explain more of the variation in party support than retrospective voting. Figures 3 and 4 below graphically depict the effects in terms of predicted probabilities. 

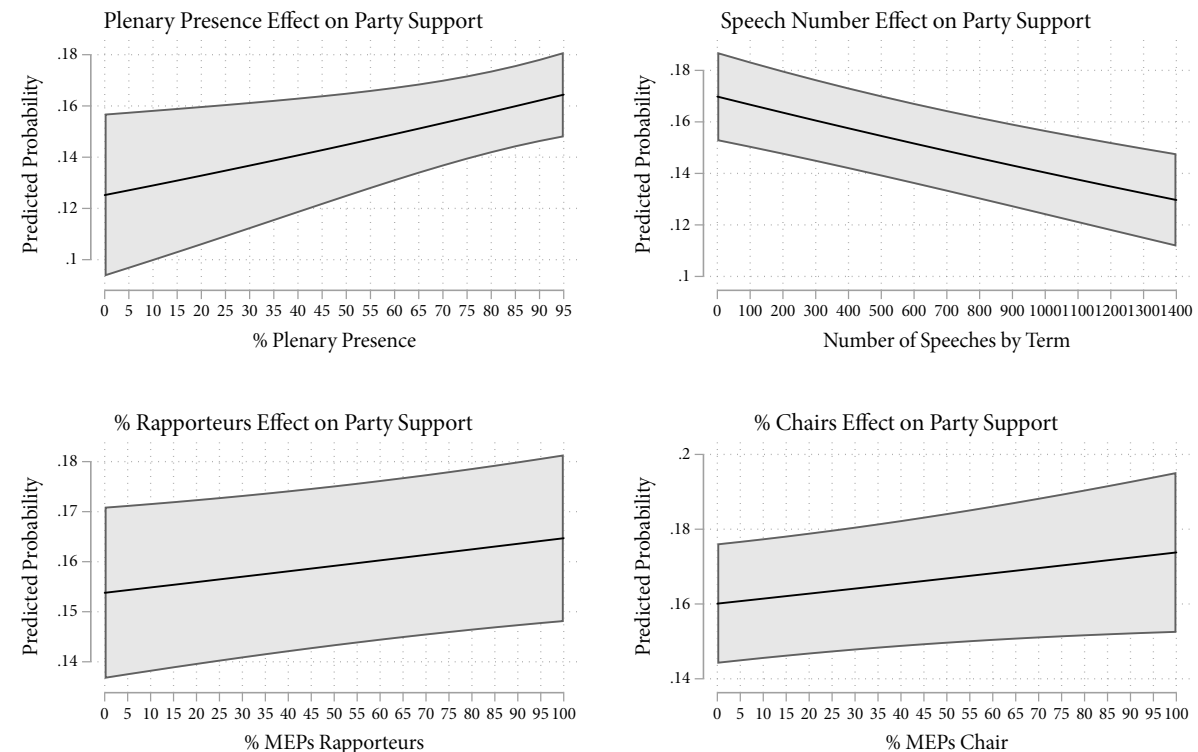

Figure 3: Predicted Probabilities of Party Vote by Parties' Legislative Activity

Note: Full Model Results.
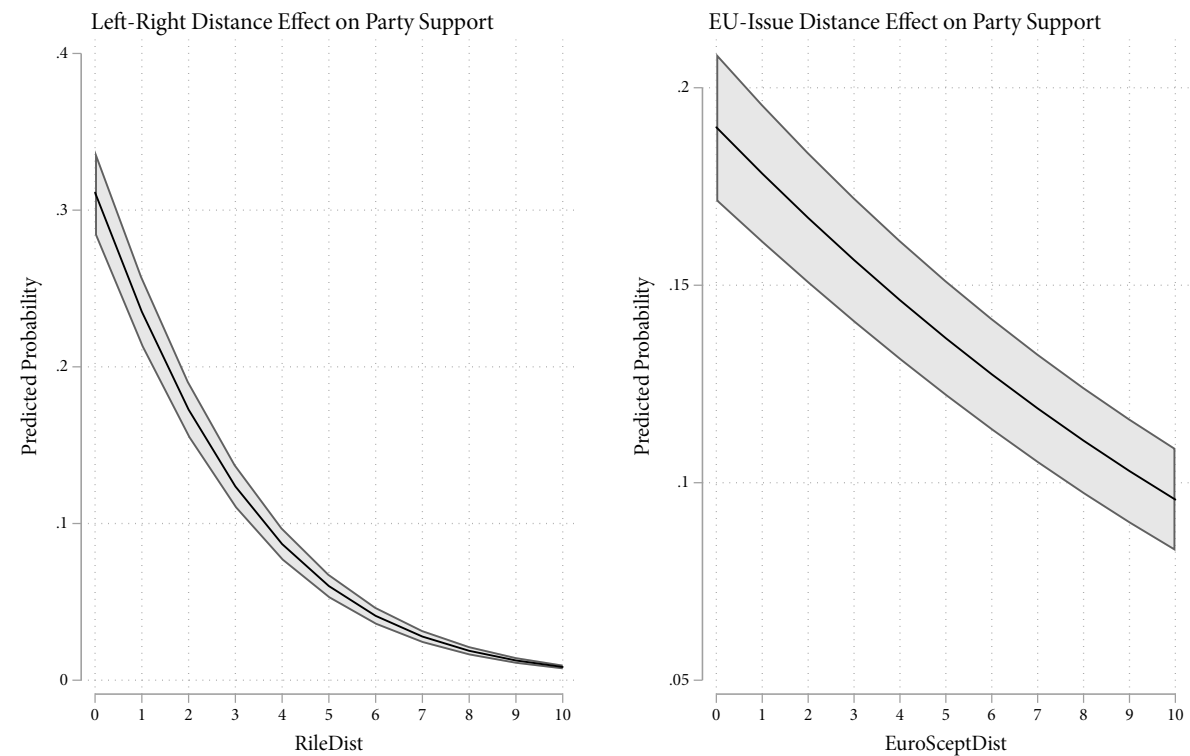

Figure 4: Predicted Probabilities of Party Vote by Parties' Ideological Congruence

Note: Full Model Results. 
Parties' level of activism in EP policy-making is associated with parties' electoral support during EP elections. Productivity-based retrospective voting can thus work even in supranational, multi-level contexts. This is an important finding. Competent retrospection is crucial for accountability, but is considered a very demanding threshold for voters to meet, even in established democracies Healy and Malhotra 2013). The effects of legislative activity on voting, together with the finding on the importance of congruence in the EU issue dimension - which confirm much previous literature on voting behaviour in EP elections - casts into doubt the notion that the EP elections are 'second-order', and that they cannot function as EU-specific accountability devices. 


\section{Engaging with the Mechanism: Awareness of EP Legislative Activity}

To explore the mechanism - that voters are aware of, and pay attention to, legislative records when casting their vote - the analysis leverages the different electoral rules used by the various member states in the 2019 European elections, and a split sample analysis which takes advantage of the EES Voter Study question: "how closely did you follow the campaign ahead of the European Parliament elections?". The analysis below therefore tests hypotheses $2 \mathrm{a}$ and $2 \mathrm{~b}$ (see Table A3 in the Appendix for the full sample and split sample results).

The hypotheses are tested by means of interactions with each legislative activity and the electoral system category. MEPs, being elected in different countries each running their own election, are subject to different ballot types (closed vs. open list), and different district magnitudes (Däubler and Hix 2018). The final section of the Appendix summarises the expectations from Carey and Shugart's model, and the classification of European countries' electoral rules used in EP elections.

The interaction effects from the full model show that in electoral systems with stronger personal vote incentives - with campaigns more heavily focused on legislators' legislative records - EP-level activities do have a stronger bearing on electoral support. For example, the higher the incentives for the personal vote, the more EP plenary attendance matters for the electoral success of parties in EP elections, and especially so in electoral systems with small district magnitudes. Similarly, the proportion of the party's MEPs that served as rapporteurs leads to more electoral support for the party the more the electoral system encourages the personal vote. Speech-making's negative effects on party choice are also particularly pronounced the more the electoral system encourages the personal vote, while it seems particularly prized in closed-list systems with large DMs, where the party leadership 
heavily controls legislative speeches, counteracting the factional, grandstanding use of debates (Proksch and Slapin 2015). The interaction effects with committee chairmanships go in the opposite direction than that hypothesised: it appears that the higher the personal vote incentive, the less holding chairmanships matters for the electoral support of the relevant political party, which is puzzling. The nature of committee chairmanships - obscure leadership positions that may be more valuable for party leaderships than for voters - may provide a tentative explanation of the effects found (François and Navarro 2020). Table A3 in the Appendix also presents the same interaction model for samples of below average attention, above average attention, and very high attention voters (those scoring 10 in campaign attention). The table shows that the effects outlined above are stronger for more campaignsavvy voters: higher likelihoods of legislative records' disclosure have a particularly strong effect for voters that are paying attention to the electoral campaign, especially for 'work-horse' activities.

All in all this analysis probing the mechanism linking parties' legislative productivity and individual-level vote choice shows that EP legislative activities have a stronger impact on voters' party choice - and in the expected direction - in systems where information about such activities is expected to be more widespread, and especially so for voters that have paid a lot of attention to the EP electoral campaign. Figures 5, 6, 7, 8 depict the main interaction effects from the full sample regression model (Table A3-Appendix). 


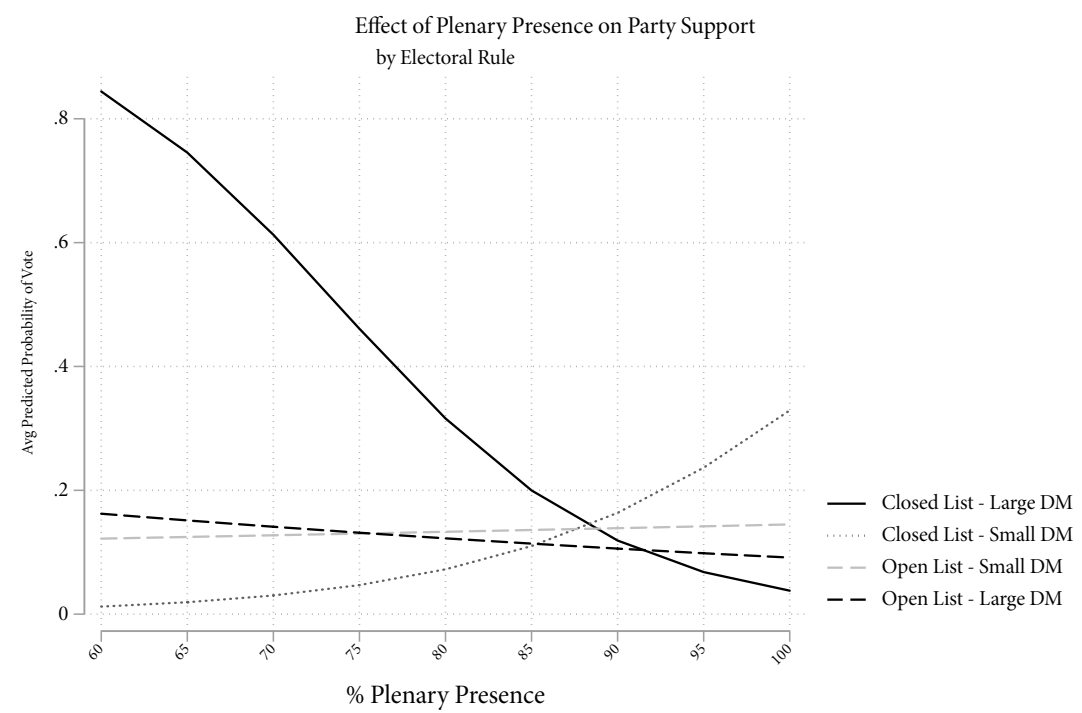

Figure 5: Interaction Effect between \% Plenary Presence and electoral rule

Note: Predicted Probabilities of Party Vote. Hierarchical Logit Model.

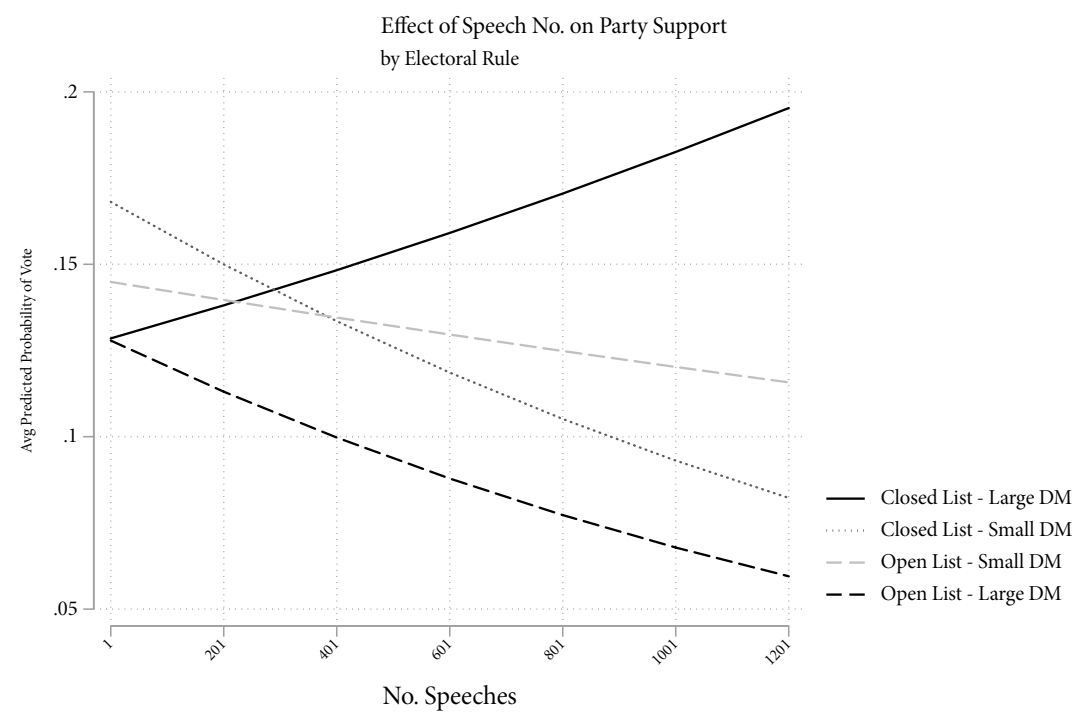

Figure 6: Interaction Effect between No. Speeches and electoral rule

Note: Predicted Probabilities of Party Vote. Hierarchical Logit Model. 


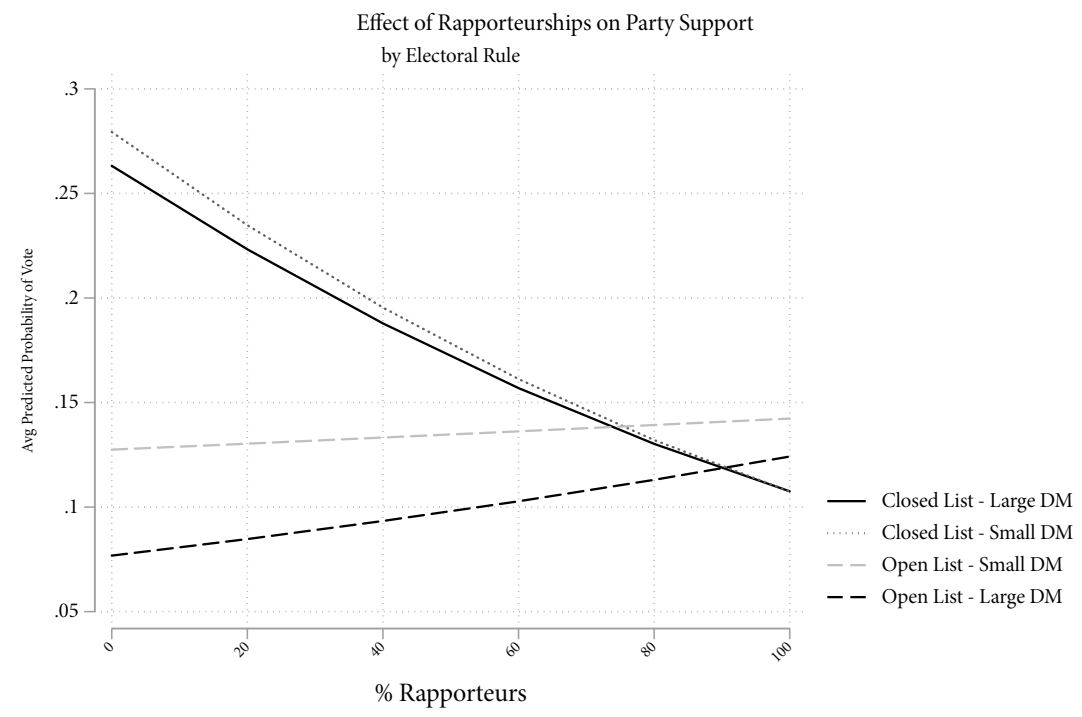

Figure 7: Interaction Effect between \% Rapporteur and electoral rule

Note: Predicted Probabilities of Party Vote. Hierarchical Logit Model.

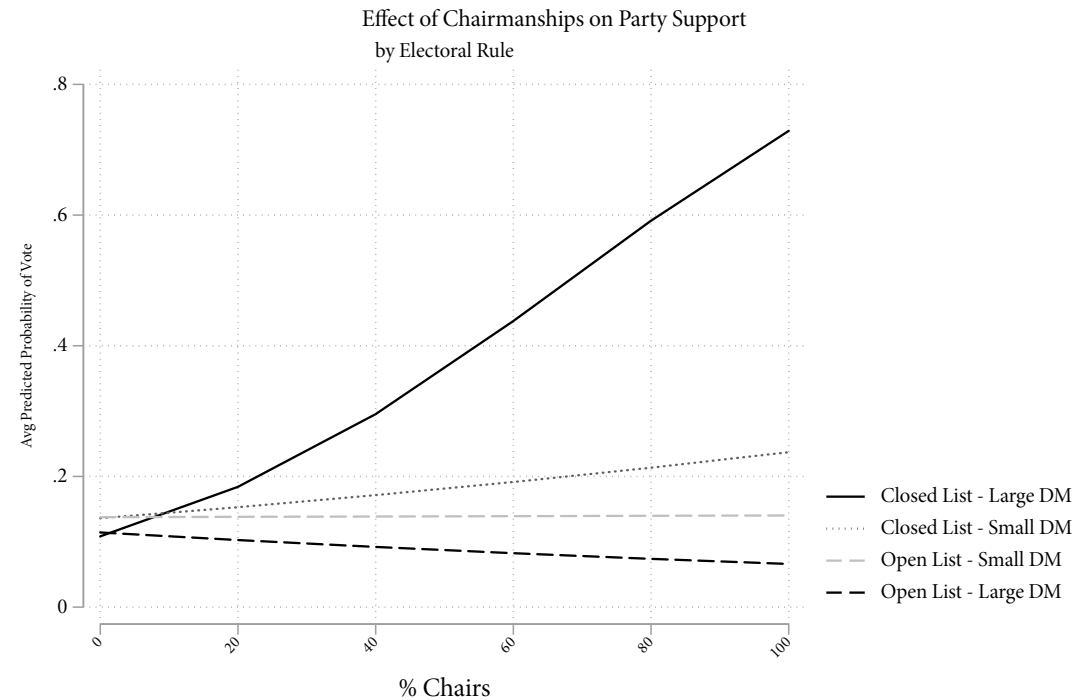

Figure 8: Interaction Effect between \% Chairs and electoral rule Note: Predicted Probabilities of Party Vote. Hierarchical Logit Model. 


\section{Conclusion}

Many characterise European Parliament elections as idiosyncratic and 'less at stake' contests. This paper tested whether a particular form of retrospective voting productivity-based retrospective voting - applies in the context of EP elections, which would constitute evidence that the normative requirement of competent retrospection applies in such a multi-level, supranational context. This calls into question the democratic deficit argument made against EP elections, and the alleged perception of European elections as sui generis and unimportant.

The models in this study test the association between national parties' activity levels in the European Parliament's 8th term (2014-2019) and voters' party choice in 2019. Controlling for governing status, party size, party family, and parties' ideological proximity on both the left-right and the EU issue dimensions - and even for partisanship (Appendix - Table A2) - there is evidence that high levels of activity in the previous EP term - especially of the 'work-horse' type - give an electoral advantage to national parties. Furthermore, it appears that electoral activity matters more for vote choice in electoral systems that encourage the personal vote, an interaction that holds especially true for voters that were highly attentive to the EP campaign. Voters that were more likely to be exposed to information about legislative records - both due to the electoral system and to their engagement with the campaign - are therefore found to be more likely to use such records to inform their vote choice, which increases confidence in the findings.

The study has implications for the broader scholarship on retrospective voting. Economic retrospective voting is a particularly difficult threshold to meet for individuals, and it can be challenged by multiple cognitive biases (Healy and Malhotra 2013). More easily accessible and non-contestable indicators are better bench- 
marks for retrospective evaluations (Ferejohn 1986). This study offers an example of successful productivity-based retrospective voting in the context of transnational multi-level elections, notoriously difficult information environments. The findings challenge the notion that holding representatives to account for different aspects of political performance is too difficult and unreasonable for citizens.

However, some activities (like plenary attendance) are more clearly positively associated to vote choice than others. It seems that 'valence' productivity - engaging in activities that are universally considered 'good' - is more important than engaging in either technical, obscure activities or 'show-horse'/theatrical ones. This is in line with what theorised by Ferejohn (1986) and with the empirical findings from the literature on the activity-vote link (Papp and Russo 2018, François and Navarro 2019; 2020). Future research should investigate the mechanism behind the association found between different activities and voting behaviour more in detail. In particular, it is important to further explore the conditions under which different legislative records can shape voting behaviour (François and Navarro 2019).

Furthermore, the paper has implications for parties' campaign strategies in European elections. Parties should capitalise on the fact that voters are keen to reward legislative activity at the EP level. Parties should therefore a) focus on EU issues in their campaigns, and b) build up and boost one's record during their time in the European Parliament.

Finally, the paper has implications for the EU's reform agenda: to ensure that European elections work as accountability mechanisms equally across the EU, it is necessary to consider a uniform electoral rule for these elections, one which manages to encourage the personal vote, as well as wider discussion of EU-level decisionmaking activities (Hix and Hagemann 2009). 


\section{References}

Achen, C. H. and L. M. Bartels (2017). Democracy for realists: Why elections do not produce responsive government, Volume 4. Princeton University Press.

Alexa (2020). Competitive Analysis, Audience Overlap \& Website Traffic Ranking.

Bartels, L. (2008). Unequal Democracy: The Political Economy of the New Gilded Age. Princeton University Press.

Bartels, L. M. (2002). Beyond the running tally: Partisan bias in political perceptions. Political behavior 24(2), 117-150.

Berry, C. R. and W. G. Howell (2007). Accountability and local elections: Rethinking retrospective voting. The Journal of Politics 69(3), 844-858.

Besley, T. (2006). Principled Agents? The Political Economy of Good Government. Oxford: Oxford University Press.

Bisgaard, M. (2015). Bias Will Find a Way: Economic Perceptions, Attributions of Blame, and Partisan-Motivated Reasoning during Crisis. The Journal of Politics $77(3), 849-860$.

Boomgaarden, H. G., C. H. De Vreese, A. R. T. Schuck, R. Azrout, M. Elenbaas, J. H. P. Van Spanje, and R. Vliegenthart (2013). Across time and space: Explaining variation in news coverage of the E uropean U nion. European Journal of Political Research 52(5), 608-629.

Bowler, S. (2010). Private Members' Bills in the UK Parliament: Is There an 'Electoral Connection'? The Journal of Legislative Studies 16(4), 476-494.

Bräuninger, T., M. Brunner, and T. Däubler (2012). Personal vote-seeking in flexible list systems: How electoral incentives shape Belgian MPs' bill initiation behaviour. European Journal of Political Research 51, 607-645.

Carey, J. M. and M. S. Shugart (1995). Incentives to Cultivate a Personal Vote: a Rank Ordering of Electoral Formulas. Electoral Studies 14(4).

Däubler, T., T. Bräuninger, and M. Brunner (2016). Is Personal Vote-Seeking Behavior Effective? Legislative Studies Quarterly 41(2), 419-444.

Däubler, T., L. Christensen, and L. Linek (2018). Parliamentary activity, re-selection and the personal vote. Evidence from flexible-list systems. Parliamentary affairs 71(4), 930-949.

Däubler, T. and S. Hix (2018). Ballot structure, list flexibility and policy representation. Journal of European Public Policy 25(12), 1798-1816. 
De Vries, C. E. and E. R. Tillman (2011). European Union issue voting in East and West Europe: The role of political context. Comparative European Politics 9(1), $1-17$.

Downs, A. (1957). An Economic Theory of Democracy. New York: Addison Wesley.

Edwards, A., D. de Kool, and C. Van Ooijen (2015). The information ecology of parliamentary monitoring websites: Pathways towards strengthening democracy. Information Polity 20(4), 253-268.

Enns, P. K., P. M. Kellstedt, and G. E. McAvoy (2012). The consequences of partisanship in economic perceptions. Public Opinion Quarterly 76(2), 287-310.

Evans, G. and R. Andersen (2006). The Political Conditioning of Economic Perceptions. The Journal of Politics 68(1), 194-207.

Evans, G. and M. Pickup (2010). Reversing the Causal Arrow: The Political Conditioning of Economic Perceptions in the 2000-2004 U.S. Presidential Election Cycle. The Journal of Politics 72(4), 1236-1251.

Farrell, D. M. and M. S. Shugart (2012). Electoral Systems. Los Angeles: SAGE.

Ferejohn, J. A. (1986). Incumbent performance and electoral control. Public Choice 50, 5-25.

Ferrara, F. and J. T. Weishaupt (2004). Get your act together: Party performance in European Parliament elections. European Union Politics 5(3), 283-306.

Ferraz, C. and F. Finan (2008). Exposing Corrupt Politicians: The Effects of Brazil's Publicly Released Audits on Electoral Outcomes. The Quarterly Journal of Economics 123(2).

Fiorina, M. P. (1978). Economic retrospective voting in American national elections: A micro-analysis. American Journal of Political Science, 426-443.

Fiorina, M. P. (1981). Retrospective voting in American national elections. New Haven: Yale University Press.

François, A. and J. Navarro (2019). Voters reward hard-working MPs: empirical evidence from the French legislative elections. European Political Science Review $11(4), 469-483$.

François, A. and J. Navarro (2020). Voters' Knowledge of Their Representatives: The Direct and Conditioned Effects of Parliamentary Work. Swiss Political Science Review 26(1), 96-124. 
Frech, E. (2016). Re-electing MEPs: The factors determining re-election probabilities. European Union Politics 17(1), 69-90.

Grier, K. B. and M. C. Munger (1986). The impact of legislator attributes on interest-group campaign contributions. Journal of Labor Research 7(4), 349-361.

Healy, A. and N. Malhotra (2013). Retrospective Voting Reconsidered. Annual Reviews of Political Science 16, 285-306.

Hermansen, S. S. L. (2018). Striving for influence: The effect of performance on candidate selection. Party Politics 24(4), 382-396.

Hix, S. and S. Hagemann (2009). The Missing Electoral Link in EU Politics. Politique Europeenne 28.

Hix, S. and M. Marsh (2010). Second-Order Effects Plus Pan-European Political Swings: An Analysis of European Parliament Elections Across Time. Electoral Studies.

Hobolt, S. B. and C. De Vries (2016). Turning against the Union? The impact of the crisis on the Eurosceptic vote in the 2014 European Parliament elections. Electoral Studies available.

Hobolt, S. B. and B. Høyland (2011). Selection and sanctioning in European parliamentary elections. British Journal of Political Science 41(3), 477-498.

Hobolt, S. B., J.-J. Spoon, and J. Tilley (2009). A vote against Europe? Explaining defection at the 1999 and 2004 European Parliament elections. British journal of political science 39(1), 93-115.

Kellermann, M. (2013). Sponsoring Early Day Motions in the British House of Commons as a Response to Electoral Vulnerability . Political Science Research and Methods 1(2), 263-280.

Key, V. O. (1966). The responsible electorate. Harvard University Press Cambridge, MA.

Kousser, T. (2004). Retrospective voting and strategic behavior in European Parliament elections. Electoral studies 23(1), 1-21.

Kramer, G. H. (1971). Short-term fluctuations in US voting behavior, 1896-1964. American political science review 65(1), 131-143.

Lewis-Beck, M. S. and M. Stegmaier (2000). Economic determinants of electoral outcomes. Annual Review of Political Science 3(1), 183-219. 
Loewen, P. J., R. Koop, J. Settle, and J. H. Fowler (2014). A natural experiment in proposal power and electoral success. American Journal of Political Science 58(1), $189-196$.

Marangoni, F. and F. Russo (2018). Not all roads lead to Rome: The conditional effect of legislative activity on reselection prospects in Italy. Parliamentary Affairs 71 (4), 888-907.

Marsh, M. and S. Mikhaylov (2010). European Parliament elections and EU governance. Living Reviews in European Governance 5.

Mayhew, D. R. (1974). Congress: The Electoral Connection (2 OP - 19 ed.). New Haven: Yale University Press.

McDermott, M. L. and D. R. Jones (2003). Do public evaluations of Congress matter? Retrospective voting in congressional elections. American Politics Research 31(2), 155-177.

McElroy, G. and K. Benoit (2010). Party Policy and Group Affiliation in the European Parliament. British Journal of Political Science 40(2), 377-398.

Okolikj, M. and S. Quinlan (2016). Context matters: Economic voting in the 2009 and 2014 European Parliament Elections. Politics and Governance 4 (1), 145-166.

Papp, Z. and F. Russo (2018). Parliamentary work, re-selection and re-election: in search of the accountability link. Parliamentary Affairs 71(4), 853-867.

Payne, J. L. (1980). Show Horses and Work Horses in the United States House of Representatives. Polity 12(3), 428-456.

Proksch, S. O. and J. B. Slapin (2012). Institutional Foundations of Legislative Speech. American Journal of Political Science 56(3), 520-537.

Proksch, S. O. and J. B. Slapin (2015). The politics of parliamentary debate. Cambridge University Press.

Reif, K. and H. Schmitt (1980). Nine Second-Order National Elections: A Conceptual Framework for the Analysis of European Elections Results. European Journal of Political Research 3, 3-44.

Schmitt, H., S. B. Hobolt, W. van der Brug, and S. A. Popa (2019). European Parliament Election Study 2019, Voter Study.

Sorace, M. and S. B. Hobolt (2020). A Tale of Two Peoples: Motivated Reasoning in the Aftermath of the Brexit Vote. Political Science Research and Methods forthcoming. 
Tilley, J., J. Garry, and T. Bold (2008). Perceptions and reality: Economic voting at the 2004 European Parliament elections. European Journal of Political Research 47(5), 665-686.

Tilley, J. and S. B. Hobolt (2011). Is the government to blame? An experimental test of how partisanship shapes perceptions of performance and responsibility. The Journal of Politics 73(2), 316-330.

Van der Eijk, C., W. Van der Brug, M. Kroh, and M. Franklin (2006). Rethinking the dependent variable in voting behavior: On the measurement and analysis of electoral utilities. Electoral Studies 25(3), 424-447.

Van Thomme, J., N. Ringe, and J. N. Victor (2015). Explaining Reelection in the European elections 2014. In Die Europawahl 2014, pp. 335-344. Springer.

Yoshinaka, A., G. McElroy, and S. Bowler (2010). The Appointment of Rapporteurs in the European Parliament. Legislative Studies Quarterly XXXV(4). 